\title{
FTIR Investigations of Toxic Gases in Air Starved Enclosed Fires
}

\author{
G.E. ANDREWS, B. DAHAM, M.D. MMOLAWA, S. BOULTER, J. MITCHELL, \\ G. BURRELL, J. LEDGER, W. GUNAMUSA, R.A. BOREHAM, \\ and H.N. PHYLAKTOU \\ Energy and Resources Research Institute \\ School of Process \\ Environment and Materials Engineering \\ The University of Leeds \\ Leeds, LS2 9JT, UK
}

\begin{abstract}
Toxic gases in air starved fires in rooms where the ventilation flow areas are very small, were investigated in a $1.57 \mathrm{~m}^{3}$ fire enclosure with 2.7 air changes an hour. Three fires were investigated: kerosene and diesel pool fires and a pine wood crib fire and all had a similar total heat release. The results showed that air starved fires develop slowly with low fire temperatures and overall lean mixtures. CO levels were relatively low and FTIR analysis of 23 toxic gases showed that aldehydes, acrolein, acetic acid, $\mathrm{SO}_{2}, \mathrm{NO}_{2}$ and some toxic hydrocarbons had a combined toxicity that was much greater than that due to CO. The wood fire had particularly high acrolein, aldehydes and acetic acid levels. The toxicity of the complex mixture of fire toxic gases was assessed using the $\mathrm{COSHH}$ $15 \mathrm{~min}$. exposure limit as the reference limiting toxic concentration.
\end{abstract}

KEYWORDS: enclosed fires, fire toxicity, acrolein, pool fires, wood crib fires

\section{INTRODUCTION}

The Rose Park nursing home fire [1] in Edinburgh killed 14 people from toxic acidic gases under circumstances where the fire did not cause much damage and had hardly spread from an enclosed linen store room. This paper investigates the toxic products in such small closed room fires, with the aim at further understanding the toxic gases produced in these circumstances. Most of the experimental work on ventilation controlled compartment fires have been carried out under conditions of high ventilation that corresponds to a door or window being open [2]. If a fire starts in a room that has today's level of passive fire protection and energy conservation and fire protection instructions are followed in closing doors and windows, then the ventilation rates are very low and similar to the leak rates for smoke in the design of fire doors [3]. It is well known that heat release rates and hence fire temperatures in enclosed fires are dependent on the air ventilation rate. Hence, in rooms with correctly designed passive fire protection the ventilation rates are very low and as a consequence fire development is very slow. In spite of their importance and relevance to fires such as those of the Rose Park nursing home fire, air starved fires have received little experimental study and most of the publications for toxic yield in fires have been for well ventilated fires.

Andrews et al. [2,4,5] introduced a ventilation parameter $K_{\text {in }}$ that is the air in leakage equivalent open area, $A_{\mathrm{v}}$, divided by the cross sectional area of a cubic room of equivalent volume $(V)$ to the test room. This definition allows air in leakage to be assessed for any shape of room. The definition may also be expressed as in Eq. 1 
Andrews et al. showed that $K_{\text {in }}$ would range from $0.09 \%$ to $0.6 \%$ if the design guides for passive fire protection and fire doors were followed [1-5]. The lowest values of $K_{\text {in }}$ that have been studied prior to the work of the authors was $1.32 \%$ in the work of Sugawa et al. [6] and the next lowest was $1.7 \%$ by Peatross and Beyler [7] and $1.9 \%$ by Audouin et al. [8]. Of the experiments with a door or window open the lowest $K_{\text {in }}$ was $4.4 \%$ by Gottuk et al., [9,10], Peatross and Beyler [7] studied $K_{\text {in }}$ of 2.7 and 6.8\%, Fleischmann, C.M. and Parkes, A.R. [11] used a ventilated fire enclosure with $K_{\text {in }}=9.2 \%$ and Chamberlain [12] used a large enclosure with $K_{\text {in }}$ of 9.4 and 26\%. Ohmiya et al. [13] used a test facility of very similar size to that used in the present work, but with conventional open fire doors with $K_{\text {in }}$ of $19 \%, 28.5 \%$ and $38 \%$. These are very high fire door areas and could only be produced by a very large door in a small room or a double door in a normal sized domestic lounge. These workers have also used a smaller cubic fire enclosure [14] with a more sensible range of $K_{\text {in }}$ from $4 \%$ to $16 \%$. In both cases the fires were shown to be ventilation controlled, in that the heat release rate was still controlled by the air flow even though this was very large. In a typical $40 \mathrm{~m}^{3}$ room with a door fully open $K_{\text {in }}$ is of the order of $17 \%$ and an open window has a $K_{\text {in }}$ of about $5 \%$. These open window and door scenarios has been the order of fire ventilation used by most investigators of enclosed fires. If a room is very large, such as an atrium, then the additional air admitted through an open door is less significant and $K_{\text {in }}$ can be small in these circumstances. The object of the present work is the determination of toxic products from fires in small rooms that have good passive fire protection with low (air starved) ventilation rates.

Andrews et al. [2,4,5] have previously investigated fires with $K_{\text {in }}$ of $0,0.126 \%$ and $1.19 \%$ for a $1.56 \mathrm{~m}^{3}$ enclosure with the fire products ventilated at the ceiling level. For convenience these values of $K_{\text {in }}$ will be referred to as $0,0.1 \%$ and $1 \%$. They showed that the peak air flow rate into the pool fires used in the experiments were $0.01 \mathrm{~kg} / \mathrm{s}$ for $K_{\mathrm{in}}=0.1 \%$ and $0.042 \mathrm{~kg} / \mathrm{s}$ for $K_{\mathrm{in}}=1 \%$. For $K_{\mathrm{in}}=0.1 \%$ the heat release rate was roughly constant after the first period (60 s) when the air in the fire enclosure was consumed in the initial period of the fire. The entrained air flow rate was also roughly constant after 60 $\mathrm{s}$ and this lasted until all the fuel at the start of the fire was consumed (1000 s). It was these results that led to the present procedure of investigating a fire development at an imposed constant air feed rate, as this was a more controlled experiment than varying the air leakage hole size to achieve a particular air flow rate. The fire enclosure had $1.87 \mathrm{~kg}$ of air at the start of the fire and the air ventilation rates correspond to 19 and 89 air changes per hour respectively.

Smoke control standards [2] have maximum allowable gaps that convert to a $K_{\text {in }}$ of $0.06 \%$, which would give about 9 air changes an hour in the present test facility. In general only about half the area would be available for air in-leakage as the fire products would leak out in the upper part of the door edge leakage area, thus ventilation rates will then be of the order of 4 air changes an hour. The present work uses 2.7 air changes an hour as more representatives of current smoke leakage paths rather than the maximum allowed in the standards. Also for heat conservation reasons, air leakage into rooms is being controlled at lower levels in modern buildings. 


\section{TOXIC GASES FROM ENCLOSED FIRES}

Over $70 \%$ of fire fatalities are caused by inhalation of toxic gases present in fire smoke $[15,16]$. Not only does smoke reduce the visibility of occupants in compartment fires, but it also is an irritant which causes impaired vision and respiratory problems. Purser [16] showed that in most fires the main toxic products are CO, HCN and irritant or acidic gases and the amounts depend on the thermal decomposition of the fire load, which depends on the temperature and oxygen supply. Although irritant and acidic gases are often quoted as being present in fires, from the reaction of those affected, there are very few measurements of these gases. The present work uses Fourier Transfer Infra Red Spectroscopy (FTIR) specifically to investigate these irritant and acidic gases. The FTIR used measures 51 species simultaneously and 23 of these are toxic, only the most toxic of these will be reported in the present results. Carbon monoxide is a colorless odorless gas and does not give the symptoms of irritant and acidic gases that are reported by surviving victims from fires, $\mathrm{CO}$ is a silent killer gas but it has to be in relatively high concentrations $\sim>3000 \mathrm{ppm}$ to cause death.

A typical enclosed fire toxic gas study is that of Hartzell [17] in a fully furnished hotel room. CO levels were up to $7 \%$ in the fire room and $1 \%$ in a remote room down the corridor $5 \mathrm{~m}$ away. The peak HCN figures were 1200 and $150 \mathrm{ppm}$ respectively. It is the spread of toxic gases from the fire room through leaks at the ceiling level that can lead to deaths in adjacent rooms, even if there is no flame spread of the fire from the room of origin, as occurred in the Rose Park fire [1]. In the Hartzell [17] study the peak fire temperature was $800^{\circ} \mathrm{C}$ and oxygen levels were zero. This is a typically highly ventilated fire and the test was carried out with an open door, which is unrealistic as all hotels have bedrooms fitted with self closing fire doors. The zero oxygen results and the very high CO level indicates that the fire was burning rich i.e., in spite of the open door the fire could not get sufficient air to burn all the fuel. This is the situation in most enclosed fire studies that are carried out with a door or window open and all show very high CO levels through rich combustion [9-13]. The reason for this is that the mass burn rate in an enclosed fire is a function of the air supplied and hence with a door open a fire has very high air supply rates and hence very intense fires.

The yield of toxic products in fires is a function of the fire equivalence ratio [18]. Consequently tabulations of fire product yields measured in freely ventilated equipment, such as Cone Calorimeters, may not be representative of the actual yields in enclosed air starved fires. To evaluate the overall toxicity of a fire with many toxic products is an area of difficulty. Levin [19] and Babrauskas et al. [20,21] introduced a N-GAS model on the toxicological interactions of seven gases $\left(\mathrm{CO}, \mathrm{CO}_{2}, \mathrm{HCN}, \mathrm{NO}_{2}\right.$, low $\mathrm{O}_{2}, \mathrm{HCl}$ and $\mathrm{HBr}$ ) which has been included in ASTM E1678 and ISO 13344. In the present work $\mathrm{HCl}$ and $\mathrm{HBr}$ are not present. The N-GAS model uses the ratio of the measured fire concentration of each of the seven toxic gases to the lethal concentration where $50 \%$ of animals die in tests, $\mathrm{LC}_{50}$. The summation of the 7 relative toxicity terms gives the overall $\mathrm{N}$ Gas value. The principle of this model is followed in the present work, but as the N-GAS model does not include any irritant or acidic gas it is thus not suitable for the present purposes. In DD240 a similar approach was advocated with mixtures of toxic gases being considered additive but based on an exposure dose (concentration $\mathrm{x}$ time) using a five minute maximum tolerable exposure basis and not $\mathrm{LC}_{50}$.

It is questionable whether toxicity levels based on death measurements are suitable for situations where the objective is to get people out of a fire alive. There are also relatively few $\mathrm{LC}_{50}$ measurements and an incomplete assessment of toxicity results if all the 
significant toxic gases are not included. In the present work the European Community COSHH (Control of Substances Hazardous to Health Regulations [22]) workplace 15 minute maximum allowable toxic concentrations are used as these are legally binding exposure levels and are available for a much wider range of toxic gases of relevance to fires, than any of the fire specific toxicity data. This procedure allows the maximum exposure for people to escape from a fire alive to be predicted rather than the present procedures of predicting the exposure levels in fires that will cause death. 15 minutes is a typical exposure time to toxic gases in large fires and this is considered a realistic basis for fire toxicity to be assessed in terms of safe evacuation. Also the COSHH Regulations include procedures for mixtures of toxic gases, which is the same as N-Gas procedures discussed above, but extended to all the toxic gases that are present.

Table 1 compares several methods of assessing toxicity for gases that are found in fire products, all of which are measured using FTIR in the present work. The inclusion of

Table 1. Toxic gas concentration limits ppm (OSHA, COSHH, EU).

\begin{tabular}{|c|c|c|c|c|c|c|c|}
\hline Toxic Gas & & $\begin{array}{c}15 \text { Min } \\
\text { Exposure } \\
\text { Limit } \\
\text { COSHH } \\
\text { [22] } \\
\end{array}$ & $\begin{array}{c}\text { Threshold } \\
\text { Limit } \\
\text { Value } \\
\text { TLV }\end{array}$ & $\begin{array}{c}\text { Short Term } \\
\text { Exposure } \\
\text { Limit } \\
\text { STEL }\end{array}$ & $\begin{array}{c}\text { Immediately } \\
\text { Dangerous to } \\
\text { Life } \\
\text { And Health } \\
\text { IDLH } \\
\end{array}$ & $\begin{array}{c}5 \text { Min } \\
\text { Tenability } \\
\text { Limit } \\
\text { DD240 }\end{array}$ & $\begin{array}{c}\mathbf{L C}_{50} \\
30 \mathrm{~min} \\
(23,24)\end{array}$ \\
\hline $\begin{array}{c}\text { Carbon } \\
\text { Monoxide }\end{array}$ & $\mathrm{CO}$ & 200 & 20 & 100 & 1200 & 10,000 & 3,000 \\
\hline Nitric Oxide & NO & 35 & 25 & & 100 & & 2,500 \\
\hline $\begin{array}{l}\text { Nitrogen } \\
\text { Dioxide }\end{array}$ & $\mathrm{NO}_{2}$ & 5 & 0.2 & 5 & 20 & 80 & 500 \\
\hline $\begin{array}{l}\text { Hydrogen } \\
\text { Cyanide }\end{array}$ & HCN & 10 & & 4.7 & 50 & 100 & 135 \\
\hline 1,3 Butadiene & $\mathrm{C}_{4} \mathrm{H}_{6}$ & & 2 & 1000 & 2000 & & \\
\hline Benzene & $\mathrm{C}_{6} \mathrm{H}_{6}$ & 3 & & & & & \\
\hline Toluene & $\mathrm{C}_{7} \mathrm{H}_{8}$ & 150 & & & & & \\
\hline Xylenes & $\mathrm{C}_{8} \mathrm{H}_{10}$ & 150 & & & $100(\mathrm{EU})$ & & \\
\hline $\begin{array}{c}\text { Trimethylben } \\
\text { zenes } \\
\end{array}$ & $\mathrm{C}_{9} \mathrm{H}_{12}$ & 25 & & & & & \\
\hline Napthalenes & $\mathrm{C}_{10} \mathrm{H}_{8}$ & 15 & & & & & \\
\hline Methanol & $\begin{array}{c}\mathrm{CH}_{3} \mathrm{O} \\
\mathrm{H} \\
\end{array}$ & 250 & & & & & \\
\hline Ethanol & $\begin{array}{c}\mathrm{C}_{2} \mathrm{H}_{5} \mathrm{O} \\
\mathrm{H} \\
\end{array}$ & 1000 & & & & & \\
\hline Acetaldehyde & $\mathrm{C}_{2} \mathrm{H}_{4} \mathrm{O}$ & 50 & & 25 & 200 & & 20,000 \\
\hline Formaldehyde & $\mathrm{CH}_{2} \mathrm{O}$ & 2 & & & & & 250 \\
\hline Acrolein & $\mathrm{C}_{3} \mathrm{H}_{5} \mathrm{O}$ & & 0.1 & $\begin{array}{c}0.3, \\
0.05(\mathrm{EU}) \\
\end{array}$ & 2 & 2 & 300 \\
\hline Acetic Acid & $\begin{array}{c}\mathrm{C}_{2} \mathrm{H}_{4} \mathrm{O} \\
2 \\
\end{array}$ & 15 & 10 & 15 & 50 & & 11,000 \\
\hline Formic Acid & $\mathrm{CH}_{2} \mathrm{O}_{2}$ & 5 & & & & & \\
\hline $\mathrm{SO} 2$ & $\mathrm{SO}_{2}$ & 5 & & & & 30 & 500 \\
\hline $\mathrm{HCl}$ & $\mathrm{HCl}$ & 5 & & & & 200 & 3,700 \\
\hline $\mathrm{HF}$ & $\mathrm{HF}$ & 3 & & & & 120 & 2,000 \\
\hline $\mathrm{HBr}$ & $\mathrm{HBr}$ & 3 & & & & 200 & 3,000 \\
\hline
\end{tabular}

$\mathrm{CO}_{2}$ and $\mathrm{O}_{2}$ depletion in the model is relevant for consideration of the risk to people in the room of origin. However, in the present work it is the risk to people outside of the room of fire origin that is of concern. Toxic gases that leak from a room are diluted by air and the $\mathrm{CO}_{2}$ and $\mathrm{O}_{2}$ depletion levels inside the room are not really significant. It is proposed to ignore them in the toxicity evaluation. In the present work 23 toxic gases were measured and their relative toxicity determined as a ratio to the COSHH 15 minute exposure data in Table 1 . The summation of the 23 relative toxicities, as recommended in the COSHH procedures [23], will give an overall relative toxicity, $\mathrm{N}$, from which the 
importance of any individual toxic gas can be determined. $\mathrm{N}$ will be much higher than 1 and will essentially give the level of air dilution of the toxic gases that are required to reduced the fire gas leakage to tolerable levels.

Table 1 shows a range of methods for expressing gas toxicity based on occupational exposure legislation for comparison with $\mathrm{LC}_{50}$ data. Although the relative toxicity for $\mathrm{CO}$ and $\mathrm{HCN}$ are similar for $\mathrm{LC}_{50}$ and occupational exposure data, comparison with other gases show major disagreements in the irritant and acidic gases areas of acetaldehyde, acrolein and acetic acid. The $\mathrm{LC}_{50}$ data requires about 10 times higher concentrations of these gases relative to $\mathrm{CO}$ than the $\mathrm{COSHH}$ data, which is considered to be much more reliable as it is part of statutory law in the EU. It also exists for a much wider range of toxic substances than for the $\mathrm{LC}_{50}$ data. Consequently the EU 15 minute maximum exposure COSHH data is used together with the STEL limit for gases without a COSHH limit.

The relative toxicity data for Acrolein has some uncertainty as the STEL value of $0.3 \mathrm{ppm}$ that is used is below the sensitivity of the FTIR, whereas for all other species in Table 1 the 15min COSHH exposure limit can be measured reliably. Although the resolution of the FTIR is stated by the manufacturers as $2 \mathrm{ppm}$ generally, the software does not report a value unless it is significant, i.e., it can be resolved within the recorded spectra. For Acrolein the FTIR was reporting values as low a $1 \mathrm{ppm}$, with peak values in the wood fires of nearly $200 \mathrm{ppm}$. Below this the instrument could not resolve acrolein and it has been reported as zero. This procedure may lead to an underestimation of the relative toxicity of acrolein. For the wood fires acrolein will be shown to dominate the overall toxicity and the measurement problems are insignificant for the very high values found. Acrolein does not dominate the toxicity in pool fires and hence the uncertainty in its measurement at very low values is not a critical feature of the toxicity assessment.

\section{EXPERIMENTAL TECHNIQUES}

A $1.56 \mathrm{~m}^{3}$ enclosed fire test facility, $1.4 \mathrm{~m} \times 0.92 \mathrm{~m} \times 1.22 \mathrm{~m}$, was used that has been described in detail previously [2,4,5]. It had a separate entrained air inlet at floor level and fire product exit at ceiling level. The air was fed from a compressor through a thermal mass flow meter into the fire enclosure through a plenum chamber under the fire enclosure floor with air admission to the fire chamber through four slots on the floor at the base of each wall. The enclosure ceiling was instrumented with an array of Type $\mathrm{K}$ $3 \mathrm{~mm}$ outer diameter mineral insulated exposed junction thermocouples. After the fire developed the ceiling temperature was uniform. The fire product gases flowed across the ceiling and were exhausted from the fire through four slots around the periphery. The products flowed along the backside of the ceiling and out through a $152 \mathrm{~mm}$ short flue into a cowl and then with air entrainment into a discharge chimney with extraction fan. It was assumed that the fire product gases were well mixed at the $152 \mathrm{~mm}$ flue and gas samples for toxic gases were taken through an open ended uncooled stainless steel tube into a $190^{\circ} \mathrm{C}$ heated sample line linked to a heated filter and sample pump and then to a heated TEMET GASMET CR-Series portable FTIR [25,26].

The FTIR had a multi-pass cell with gold-coated mirrors with a $2 \mathrm{~m}$ path length and volume of 0.22 . This had an $8 \mathrm{~cm}^{-1}$ wavelength resolution and a $900-4250 \mathrm{~cm}^{-1}$ scanning range. This low resolution was used as this has a much better signal to noise ratio for complex multi-component gas analysis. A liquid nitrogen cooled MCT detector was used that scans 10 spectra per second and several scans are used to produce a time- 
averaged spectrum. The response time of the instrument is $2 \mathrm{~s}$ to reliably resolve all 51 species that it can measure (only 23 of these are toxic and only the most toxic of these of reported in Tables 2-4). For fires that develop slowly over several minutes, an overall data acquisition time at $5 \mathrm{~s}$ intervals was used and this was more than adequate to resolve the time dependent toxic gas production in fires which last for typically 30 minutes. The Temet FTIR gives a typical $2 \mathrm{ppm}$ resolution with an accuracy of $2 \%$ and a precision that is $0.01 \%$ of the measurement range. The FTIR has been calibrated for all the significant species that are present in the gas sample from fires. If parts of the measured spectrum are unaccounted for in the calibrated gases then the instrument gives a warning, but this was not a problem in the present work. The only calibration necessary prior to the test was to zero the instrument on nitrogen. The calibration was checked for some gases, CO, $\mathrm{CO}_{2}$, benzene and methane using certified span gases and the agreement was satisfactory. Only the most significant toxic species are reported here.

The experimental fires were kerosene and diesel pool fires with a $200 \mathrm{~mm}$ square pool area and $40 \mathrm{~mm}$ depth with $600 \mathrm{~g}$ of fire load [2,4,5]. Pool fires were used as they are a repeatable fire and are of direct interest as a petrochemical fire hazard, they have also been used by other investigators in enclosed fires [8-14]. In addition a wood crib fire was studied using 50 pieces of square faced $18 \mathrm{~mm}$ x $18 \mathrm{~mm}$ x $200 \mathrm{~mm}$ smooth pine with a total mass of $1588 \mathrm{~g}$. The fire load total energy content was 25.8 MJ for the kerosene and diesel pool fires ( $\mathrm{CV}=43 \mathrm{MJ} / \mathrm{kg}$ ) and $27 \mathrm{MJ}$ for the pine crib fire $(\mathrm{CV}=17 \mathrm{MJ} / \mathrm{kg})$. These are very similar fire energy loads and should result in similar fire temperatures for the same air ventilation rate. Four pieces of wood were used per layer spaced at $18 \mathrm{~mm}$ and there were 12 layers with each alternate layer placed in the opposite direction. The wood crib was ignited with $10 \mathrm{~g}$ of ethanol in a small pool fire at the bottom of the crib in the centre. The pine wood used was not dried, but its water content was not determined. The presence of water absorbed into wood can lead to the formation of methanol in fires and may also lead to aldehyde formation and water may have influence their formation in this work.

For all the fires the fire load was supported on a load cell, located in the air cooled plenum chamber, so that the mass loss was recorded during the fire with a $1 \mathrm{~g}$ resolution. The air flow rate to each fire was constant at $5 \mathrm{~kg} / \mathrm{hr}$ which gave 2.7 air changes per hour. This air flow rate is equivalent to a fire ventilation $K_{\text {in }}$ of $0.02 \%$, by scaling from the work of Andrews et al. [2,4,5] using the orifice flow equation for the same air flow pressure loss. This ventilation rate corresponds to that in a room with doors and windows closed and no air in leakage, apart from the small gap around the bottom of the door. The fire outlet area in the ceiling was much larger than the inlet air flow area and the fire development was controlled by this low inlet air flow rate.

\section{FIRE MASS LOSS AND MEAN CEILING TEMPERATURE}

The fire mass loss as a percentage of the initial mass is shown as a function of time in Fig. 1 and the mean ceiling fire temperature in Fig. 2 for all three fire loads. The diesel and kerosene pool fires had a similar initial fire development, but the kerosene fire did not develop after 10 mins and burned with a weak flame and then self extinguished. The oxygen level in the fire started to increase and the CO to decrease after 10 minutes. This resulted in the fire temperature falling sharply for the kerosene fire after $10 \mathrm{mins}$. In contrast the diesel fuel continued to burn and the peak fire temperature was higher at $290^{\circ} \mathrm{C}$ compared with $250^{\circ} \mathrm{C}$ for the kerosene fire. The pine crib burnt more slowly than the pool fires at first, as expected. However, after 8 mins., it burnt in a similar way to 
diesel, with a greater mass loss after 12 mins. This greater mass burn rate produced a higher peak temperature at $340^{\circ} \mathrm{C}$. In these fires with only 2.7 air changes an hour the initial air in the fire enclosure was a significant part of the fire. The heat released peaked in the early part of the fire, $14.7 \mathrm{~kW}$ for kerosene, $13.5 \mathrm{~kW}$ for diesel and $27.9 \mathrm{~kW}$ for pine. These low heat release rates are typical of air starved fires.

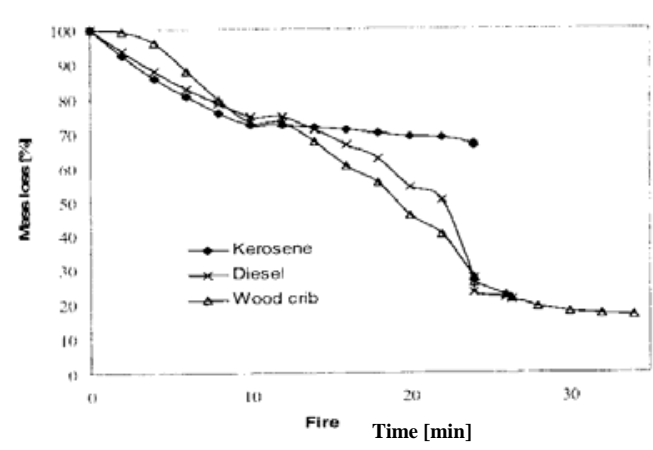

Fig. 1. Fuel mass loss v. time.

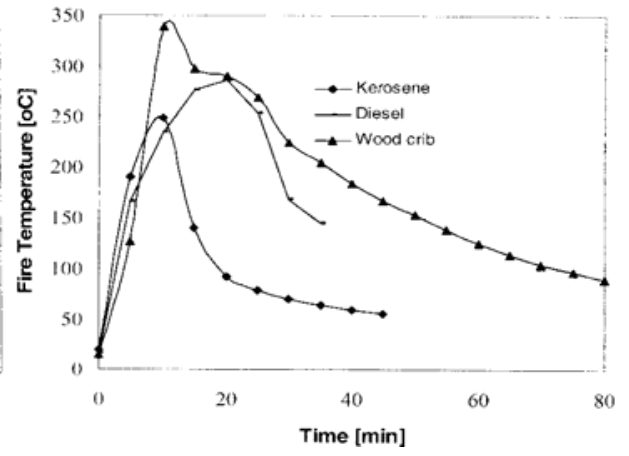

Fig. 2. Mean fire ceiling temperature v. time.

\section{FTIR TOXIC GAS ANALYSIS}

The FTIR analysis are presented for the most toxic species in Tables 2-4 for kerosene, diesel and pine wood fires. In these fires several toxic gases were monitored and found to be insignificant relative to their $15 \mathrm{~min}$. COSHH limit in Table 1: $\mathrm{N}_{2} \mathrm{O}, \mathrm{COS}, \mathrm{HCl}, \mathrm{HF}$, 1,3,5 trimethylbenzene, ethylnaphthalene, methanol, ethanol, $\mathrm{o}$ and $\mathrm{p}$ xylene,Acetaldehyde and 1,3 Butadiene. Formic and acetic acids were not significant for pool fires and m-xylene and Napthalenes were not significant for pine fires.

A significant feature of the pool fires was the generation of HCN at levels that were a toxic hazard for a long period in the fires. This effect was much lower in the pine wood crib fires, apart from a short period in the fire around 15 minutes. Liquid fuels contain low level fuel nitrogen and a typical level for diesel is $100 \mathrm{ppm}$. Local rich burning of fuels that contain fuel nitrogen will generate HCN. However, these same rich regions can also generate HCN through reactions between air nitrogen and hydrocarbons. This must be the source of HCN in the pine wood cribs as there is normally negligible organically bound nitrogen in wood. The other toxic nitrogen species was $\mathrm{NO}$ and $\mathrm{NO}_{2}$ and these were present at significant toxic levels for mainly $\mathrm{NO}_{2}$ in the later stages of the fire, through reactions between $\mathrm{NO}$ and $\mathrm{HO}_{2}$ flame radicals. There was only $\mathrm{NO}_{2}$ in diesel pool fires. This was much less of a problem in the wood fires. The present ventilation starved fires did not burn with high temperatures, which are necessary to generated large amounts of NO.

In all the fires $\mathrm{SO}_{2}$ was a significant toxic gas. This was expected for kerosene and diesel which have around 500 ppm S in the fuels. However, it was not expected for pine wood, but this has $\mathrm{SO}_{2}$ levels as high as the peak in the pool fires for 40 minutes in the fire. There must be significant sulphur levels in the wood used. This could come from wood preservative treatments. 
Table 2. Kerosene FTIR toxic gas analysis (ppm).

\begin{tabular}{|c|c|c|c|c|c|c|c|c|c|c|c|}
\hline 竞 & $\stackrel{\circ}{z}$ & $\stackrel{0}{ }^{\sim}$ & $\underset{U}{Z}$ & ڤั๊๊̃ & : & 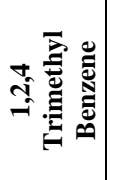 & 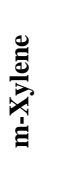 & రీ $^{N}$ & 总 & 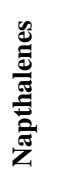 & 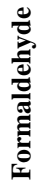 \\
\hline 2 & 0 & 1 & 4 & 10 & 3 & 1 & 0 & 3 & 0 & 0 & 5 \\
\hline 5 & 4 & 2 & 36 & 130 & 37 & 13 & 4 & 17 & 13 & 23 & 94 \\
\hline 10 & 57 & 4 & 25 & 87 & 45 & 6 & 13 & 10 & 8 & 23 & 98 \\
\hline 15 & 18 & 11 & 14 & 110 & 360 & 0 & 128 & 5 & 0 & 22 & 27 \\
\hline 20 & 0 & 13 & 7 & 83 & 288 & 0 & 195 & 3 & 0 & 18 & 10 \\
\hline 25 & 15 & 3 & 5 & 55 & 246 & 18 & 151 & 2 & 0 & 15 & 4 \\
\hline 30 & 5 & 3 & 4 & 40 & 200 & 11 & 250 & 2 & 0 & 12 & 60 \\
\hline 35 & 30 & 3 & 0 & 10 & 125 & 10 & 300 & 5 & 0 & 11 & 65 \\
\hline 40 & 35 & 5 & 0 & 0 & 200 & 0 & 150 & 5 & 0 & 12 & 70 \\
\hline
\end{tabular}

Table 3. FTIR toxic gas analysis for diesel fire (ppm).

\begin{tabular}{|c|c|c|c|c|c|c|c|c|c|c|}
\hline 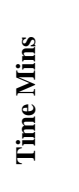 & 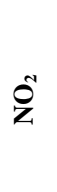 & Z & 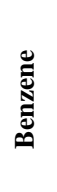 & 苞 & 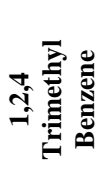 & 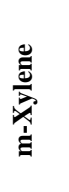 & ̊ే & 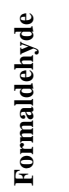 & $\frac{\pi}{\frac{0}{0}}$ & 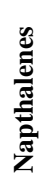 \\
\hline 2 & 4 & 6 & 27 & 13 & 1 & 0 & 3 & 23 & 1 & 7 \\
\hline 5 & 4 & 22 & 78 & 29 & 0 & 0 & 12 & 79 & 3 & 24 \\
\hline 10 & 4 & 13 & 53 & 14 & 0 & 0 & 12 & 66 & 5 & 17 \\
\hline 15 & 6 & 11 & 50 & 13 & 5 & 0 & 14 & 70 & 4 & 18 \\
\hline 20 & 6 & 15 & 56 & 7 & 4 & 0 & 18 & 81 & 2 & 20 \\
\hline 25 & 5 & 14 & 46 & 7 & 5 & 0 & 18 & 80 & 3 & 19 \\
\hline 30 & 7 & 18 & 64 & 5 & 10 & 0 & 24 & 90 & 6 & 19 \\
\hline 35 & 16 & 7 & 20 & 224 & 0 & 146 & 12 & 108 & 0 & 26 \\
\hline 40 & 14 & 2 & 10 & 200 & 0 & 235 & 4 & 22 & 0 & 20 \\
\hline 45 & 10 & 2 & 0 & $186^{\prime}$ & 0 & 500 & 2 & 59 & 0 & 11 \\
\hline
\end{tabular}

Table 4. FTIR toxic gas analysis for pine wood crib fire (ppm).

\begin{tabular}{|c|c|c|c|c|c|c|c|c|c|c|c|c|}
\hline 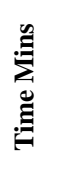 & そ & z & Z & ڤั๊ & 苞 & 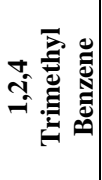 & ల్ర & 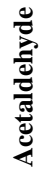 & 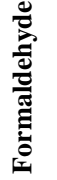 & $\frac{5}{\frac{0}{0}}$ & 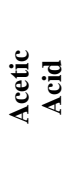 & 裉 \\
\hline 2 & 0 & 0 & 1 & 2 & 3 & 0 & 0 & 0 & 5 & 0 & 0 & 0 \\
\hline 5 & 0 & 0 & 1 & 5 & 20 & 0 & 0 & 3 & 40 & 0 & 5 & 1 \\
\hline 10 & 3 & 1 & 4 & 15 & 25 & 45 & 17 & 28 & 149 & 22 & 31 & 5 \\
\hline 15 & 51 & 3 & 15 & 15 & 6 & 107 & 34 & 86 & 334 & 98 & 111 & 8 \\
\hline 20 & 79 & 6 & 10 & 5 & 30 & 105 & 25 & 85 & 400 & 93 & 152 & 15 \\
\hline 25 & 5 & 1 & 9 & 0 & 36 & 125 & 45 & 81 & 371 & 137 & 163 & 20 \\
\hline 30 & 0 & 0 & 8 & 0 & 80 & 94 & 41 & 60 & 338 & 193 & 170 & 21 \\
\hline 35 & 50 & 3 & 7 & 5 & 110 & 72 & 21 & 24 & 297 & 134 & 132 & 18 \\
\hline 40 & 65 & 0 & 7 & 10 & 87 & 70 & 17 & 12 & 272 & 122 & 115 & 16 \\
\hline 45 & 25 & 0 & 0 & 5 & 25 & 35 & 39 & 2 & 217 & 65 & 85 & 19 \\
\hline 50 & 0 & 0 & 0 & 12 & 15 & 21 & 16 & 2 & 192 & 27 & 69 & 17 \\
\hline 60 & 5 & 0 & 0 & 0 & 27 & 2 & 0 & 0 & 142 & 11 & 46 & 11 \\
\hline 70 & 0 & 1 & 0 & 12 & 10 & 0 & 0 & 0 & 103 & 5 & 37 & 9 \\
\hline
\end{tabular}


The main hydrocarbons of toxic significance were benzene, toluene, $\mathrm{m}$-xylene and naphalenes for kerosene and diesel pool fires. For pine wood fires benzene was still significant but none of the others were. However, 1,2,4 trimethyl benzene was a significant toxic hydrocarbon product in the pine wood fires and this was negligible in the pool fires. These compounds are pyrolysis products in the fire as kerosene, diesel and wood do not contain this hydrocarbon. The major other toxic gases generated in the fires were oxygenated hydrocarbons in the form of aldehydes and acidic gases such as acetic acid. In the kerosene and diesel fires formaldehdye and acrolein were the main toxic gases of this type. For wood fires the problem with these gases was much worse due to the $40 \%$ oxygen in the wood that assists in the pyrolysis of oxygenated hydrocarbons. Acetaldehyde and formaldehyde were above toxic levels and acrolein, formic and acetic acids were extremely high. The combination of these gases are the irritant and acidic gases referred to by those caught breathing this type of fire toxic gas. These high concentrations of toxic oxygenated hydrocarbons are the main difference between the hydrocarbon pool fires and the pine wood crib fires.

Wood fires are typical of cellulose type fire materials and these toxic gases are likely to have been important in the Rose Park [1] fire. It is considered that it is the low temperatures of these air starved fires that is crucial in the production of these partially oxidised hydrocarbons. In fires with more ventilation the fire intensity increases and the temperature rises and these compounds are burnt to completion. At high temperature the hydrocarbons released from the wood pyrolysis are readily oxidised and partial oxidation products are less likely. In this type of fire CO becomes the dominant toxic gas, but this is not the case in the present work.

The above toxic gas concentrations were converted into a relative toxicity by dividing each concentration by the COSHH 15 min. exposure limits given in Table 1. For acrolein the $0.3 \mathrm{ppm}$ STEL limit has been used as the 2001 COSHH tables do not have a value for acrolein. For 1,3 Butadiene the COSHH tables also have no value and the STEL 1000 ppm value has been used. This is a contentious value as the TLV is $2 \mathrm{ppm}$ and 1,3 Butadiene is a know carcinogen that is environmentally controlled in the USA. The effect of using a $1000 \mathrm{ppm}$ toxicity value is to remove 1,3 Butadiene as a toxic hazard. However, if the $2 \mathrm{ppm}$ value was used then 1,3 Butadiene would be a significant contributor to toxicity, as concentrations of 20-30 ppm were found in all three fires.

A major impact on the toxicity assessment is the very low COSHH toxic levels for acetaldehyde compared with the very high $\mathrm{LC}_{50}$ levels, with similar considerations applying to acrolein and acetic acid. The present assessment puts these gases as the major contributions to toxicity. This does confirm experience in that irritant acidic gases are a very common experience of people exposed to toxic smoke in fires. The aim of using COSHH toxicity data is that this gives predictions for people to survive a fire not predictions of toxic levels for fire deaths, which is the $\mathrm{LC}_{50}$ approach. This area of relative toxicity needs further investigation.

By summating all the relative toxicity numbers an overall relative toxicity assessment, $\mathrm{N}$, is generated. These overall relative toxicity levels for all three fires are summarised in Table 5 together with the percentage contribution to the overall toxicity from the major toxic gases. This shows that in the pool fires benzene was a significant contribution to the overall toxicity together with formaldehyde. CO was of the order of $10 \%$ of the toxicity for all three fires. For the pine wood fire benzene was of lesser importance and acrolein and formaldehyde were the dominant toxics. A key difference in the fires was that the greatest overall toxicity for the pool fires was in the 5-10 minute period from the start of 
the fire, whereas in the wood crib fire this was in the smouldering stage of the fire 1550 minutes after the start of the fire. Toxic conditions lasted far longer in the wood fires than in the pool fires for the same fire loading.

Table 5. Total toxic gas relative emissions $(\mathrm{N})$ and the major contributors to the toxicity.

\begin{tabular}{|c|c|c|c|c|c|c|c|c|c|c|c|c|c|c|c|}
\hline Time & \multicolumn{5}{|c|}{ Kerosene } & \multicolumn{5}{|c|}{ Diesel } & \multicolumn{5}{|c|}{ Pine Wood } \\
\hline 首 & z & $\begin{array}{l}0 \\
\text { O } \\
\text { o }\end{array}$ & $\frac{N}{0}$ & 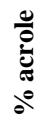 & 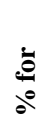 & Z & $\begin{array}{l}0 \\
\text { Oे } \\
\text { o }\end{array}$ & 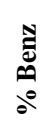 & 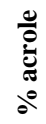 & $\underset{0}{\stackrel{\pi}{E}}$ & Z & $\begin{array}{l}0 \\
\text { O } \\
0^{\circ}\end{array}$ & $\frac{\Sigma}{0}$ & 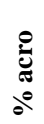 & 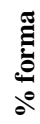 \\
\hline 2 & 10 & 30 & 32 & 0 & 24 & 30 & 14 & 30 & 10 & 40 & 3 & 12 & $\begin{array}{l}1 \\
8\end{array}$ & & 74 \\
\hline 5 & $\begin{array}{l}14 \\
5\end{array}$ & 11 & 27 & 27 & 29 & 91 & 14 & 29 & 11 & 44 & 28 & 14 & $\begin{array}{l}1 \\
8 \\
\end{array}$ & & 71 \\
\hline 10 & $\begin{array}{l}11 \\
5\end{array}$ & 12 & 22 & 21 & 38 & 72 & 14 & 25 & 24 & 46 & 179 & 10 & 3 & 41 & 41 \\
\hline 15 & 60 & 10 & 55 & 0 & 20 & 80 & 13 & 21 & 16 & 44 & 572 & 9 & 1 & 57 & 29 \\
\hline 20 & 42 & 6 & 63 & 0 & 11 & 81 & 13 & 23 & 9 & 51 & 596 & 9 & 1 & 52 & 34 \\
\hline 25 & 27 & 3 & 69 & 0 & 7 & 78 & 13 & 19 & 13 & 51 & 738 & 8 & 0 & 62 & 25 \\
\hline 30 & 49 & 1 & 27 & 0 & 6 & 93 & 13 & 23 & 22 & 48 & 915 & 8 & 0 & 70 & 18 \\
\hline 35 & 42 & 1 & 8 & 0 & 76 & 81 & 8 & 9 & 0 & 67 & 684 & 9 & 0 & 65 & 22 \\
\hline 40 & 42 & 0 & 0 & 0 & 84 & 27 & 8 & 11 & 0 & 41 & 621 & 8 & 1 & 66 & 33 \\
\hline 45 & & & & & & & & & & & 405 & 14 & 1 & 54 & 47 \\
\hline 50 & & & & & & & & & & & 232 & 13 & 2 & 39 & 41 \\
\hline
\end{tabular}

\section{CONCLUSIONS}

1. In complex fire gases there are many toxic gases and particles and the evaluation of the overall toxicity is a problem area. The COSHH 15 minute toxicity concentration were used in the present work, but there is a major discrepancy between this data and $\mathrm{LC}_{50}$ on the importance relative to $\mathrm{CO}$ of acrolein, formaldehyde and acetic acid.

2. In enclosed domestic room fires with modern passive fire protection and all doors and windows closed, the air ventilation is very low and corresponds to $K_{\text {in }}<<1 \%$, a scenario that has received little study in fire toxic gas studies.

3. A kerosene and diesel pool fire and a pine wood crib fire of total fire load 26 MJ was investigated in a $1.57 \mathrm{~m}^{3}$ enclosed fire with 2.7 air changes an hour. The result fires were all similar with low peak ceiling fire temperatures in the $250-300^{\circ} \mathrm{C}$ range. The fire duration was relatively long at over an hour for the wood fire and there was evidence of self extinguishing flames for the kerosene fire. These fire burnt overall fuel lean and CO emissions were significant but not very high.

4. A heated FTIR was used to quantify toxic gases. The results showed that for the pool fires benzene was an important toxic product, but this was not the case for the pine wood fire. Formaldehyde was a major toxic product in all three fires, mainly due to the low fire temperatures which favour aldehyde formation. For pine wood fire acrolein was a major toxic hazard.

5. The period after flaming combustion ceased was a period of significant toxic gas production, for the pool fires due to pyrolysis of the fuels at the fire enclosure hot temperatures after the fire. For the pine wood fire, smouldering combustion continued for 
a long period and significant toxic gases were produced, mainly acrolein and formaldehyde.

\section{ACKNOWLEDGEMENTS}

We would like to thank the EPSRC for the JIF LANTERN award to G.E. Andrews and others, which allowed the TEMET FTIR and heated sample system to be purchased. The EPSRC also provided studentships for G. Burrell and J. Ledger. B. Daham would like to thank the University of Leeds for a Scholarship. The enclosed fire facility was provided through a University of Leeds special equipment award.

\section{REFERENCES}

[1] Inquiry into nursing home deaths, BBC 2005, Viewed 30/5/05 <http:/news.bbc.co.uk/1/hi/Scotland/3448091.stm>.

[2] Andrews, G.E., Ledger, J., and Phylaktou, H.N., "Enclosed Pool Fire Flame Temperatures and Global Heat Loss Using Gas Analysis,” Sixth International Symposium on Fire Safety Science, 1999.

[3] BS 5588-4:1998 "Fire Precautions in the Design, Construction, and Use of Buildings.”

[4] Andrews, G.E., Ledger, J., and Phylaktou, H.N., "Pool Fires in a Low Ventilation Enclosure,” I.Chem.E. Symposium on Hazards XV, I.Chem.E. Symposium Series, No. 147, 2000, p.147-183.

[5] Andrews, G.E., Ledger, J., and Phylaktou, H.N., 'The Gravimetric Determination of Soot Yields in Enclosed Pool Fires,” Proc. $3^{\text {rd }}$ International Colloquia on Explosions in Reactive Systems, Windermere, 2000.

[6] Sugawa, O., Kawagoe, K., and Oka, Y., "Burning Behavior in a Poor-ventilation Compartment Fire - Ghosting Fire,” Nuclear Engineering and Design, 125, p. 347-352, 1991.

[7] Peatross, M.J., and Beyler, C.I., "Thermal Environment Prediction in Steel Bounded Preflashover Compartment Fires,” Proc. Fifth Int. Symp. On Fire Safety Science, 1997, p. 415-426.

[8] Audounin, I., Such, J.M., Malet, J.C., and Casselmann, C., “A Real Scenario for a Ghosting Flame,” Proc. Fifth Int. Symp. on Fire Safety Science, 1997, pp. 1261-1272.

[9] Gottuk, D.T., Roby, R.J., and Beyler, C.I., “A Study of Carbon Monoxide and Smoke Yields from Compartment Fires with External Burning," $24^{\text {th }}$ Symposium (International) on Combustion, 1992, pp. 1729-1735.

[10] Gottuk, D.T., Roby, R.J., Peatross, M.J., and Beyler, C.I., “Carbon Monoxide Production in Compartment Fires,” J. Fire Protection Engineering, 4, pp.133150, 1992.

[11] Fleischmann, C.M., and Parkes, A.R., "Effects of Ventilation on the Compartment Enhanced Mass Loss Rate,” Proc. Fifth Int. Symp. On Fire Safety Science, 1994, pp. 205-216. 
[12] Chamberlain, G.A., "The Hazards Posed by Large-scale Pool Fires in Offshore Platforms,” Trans. IChemE, 74, Part B, pp.81-87, 1996.

[13] Ohmiya, Y., Tanaka, T., and Wakamatsu, T., "A Room Fire Model for Predicting Fire Spread by External Flames,” Fire Science and Technology, 18, (1), pp. 11-21, 1998.

[14] Ohmiya, Y., Yusa, S., Suzuki, J., Koshikawa, K., and Delichatsios, M.A., "Aerothermodynamics of Fully Involved Enclosure Fires Having External Flames, In Delichatsios, M.A. and Silcock, G.W.H., Fully Involved Enclosure Fires: Effects of Fuel Type, Fuel Area and Geometry," Proc. Seventh International Symposium on Fire Safety Science, 2002, pp. 58-73.

[15] Nelson, G.L., "Carbon Monoxide and Fire Toxicity: A Review and Analysis of Recent Work,” Fire Technology, 34, p. 1, 1998.

[16] Purser, D.A., “Toxic Assessment of Combustion Products," In: Dinenno, P.J. (Ed.), SFPE Handbook of Fire Protection Engineering, Sec. 2, p. 85-146, NFPA, 1995 and $3^{\text {rd }}$ Ed. (DiNenno, P.J.), 2002, pp. 2/83-2/171.

[17] Hartzell, G.E., "Engineering Analysis of Hazard to Life Safety in Fires: The Fire Effluent Toxicity Component," Safety Science, 38, pp. 147-155, 2001.

[18] Tewarson, A., "Generation of Heat and Chemical Compounds in Fires," The SPFE Handbook of Fire Protection Engineering $3^{\text {rd }}$ Ed.' DiNenno, P.J. (Ed.), NFPA, 2002, pp. 3/83 - 3/161.

[19] Levin, B.C., "New Research Avenues in Toxicology: 7 Gas N-model Toxicant Suppressants and Genetic Toxicology,” Toxicology, 115, pp. 89-106, 1996.

[20] Babrauskas, V., Harris, R.H., Gann, R.G., Levin, B.C.,Peacock, B.T., Paabo, R.D., Harris, R.H., and Yusa, S., "A Methodology for Obtaining and Using Toxic Potency Data for Fire Analysis,” Fire Safety J., 31, pp. 345-358, 1998.

[21] Babrauskas, V., "Fire Safety Improvements in the Combustion Toxicity Area: is There a Role for LC Ln $_{0}$ Tests?” Fire and Material, 24, pp. 113-119, 2000.

[22] "Control of Substances Hazardous to Health Regulations 2002,” HSE Books, UK Health and Safety Executive.

[23] Fire Science and Technology Inc., "Toxicity of Fire Gases,” Viewed 30/5/05 $<$ http://www.acne.com/-vyto/toxicity.html>.

[24] Purser, D.A., "Toxic Product Yields and Hazard Assessment for Fully Enclosed Design Fires,” Polymer International, 49, p.1232-1255, 2000.

[25] Kauppinen, J.K. et al., “Carousel Interferometer," Applied Optics, 34 (27), pp. 6081-6084, 1995.

[26] Saarinen, P., and Kauppinen, J., "Multicomponent Analysis of FTIR Spectra," Applied Spectroscopy, 45 (6), pp. 953-963, 1991. 